\title{
Addition of Different Nitrogen Sources on the Cocoa Pod (Theobroma Cacao) fermented with
} Pleurotus Ostreatus

\author{
Junaidah $^{1}$, Nuraini ${ }^{2}$, Ade djulardi ${ }^{2}$ \\ ${ }^{1}$ Department of Animal Science, Faculty of Animal Science, Andalas University, 25163, Indonesia \\ Email: junaidasyaf@gmail.com \\ ${ }^{2}$ Department of Animal Nutrition and Feed Technology, Faculty of Animal Science, Andalas University, 25163, Indonesia
}

\begin{abstract}
This research was aimed the composition of the substrate, inoculum dose and fermentation time suitable for the growth of Pleurotus ostreatus on cocoa pod substrate mixtures with different nitrogen sources ( tofu waste, soy milk waste and rice bran) of the cellulase enzyme activity, laccase enzyme activity, crude fiber decreased, and crude fiber digestibility. This study used an experimental method with a completely randomized design (RAL) 3x3x3 factorial with 2 replications. Factor A is a substrate composition with a ratio of $80 \%$ cocoa pod and $20 \%$ for tofu waste, soy milk waste, and rice bran. Factor B is an inoculum dose of 6\%, $8 \%$ and $10 \%$ with Factor $C$ is the fermentation time of 7, 9 and 11 days. The results of the analysis showed that an interaction of the substrate composition and fermentation time with Pleurotus ostreatus which had a significant effect $(P$ $<0.05)$ of the activity of cellulase enzymes, laccase enzyme activity, crude fiber decreased and crude fiber digestion. The results of the study can be concluded that the selected treatment was found in the composition of $80 \%$ cocoa pod and $20 \%$ tofu waste with 9 days fermentation time (A1C2). In this condition cellulase enzyme activity was obtained of $2.70 \mathrm{U} / \mathrm{ml}$, the laccase enzyme activity of $12.33 \mathrm{U} / \mathrm{ml}$, crude fiber decreased of $44.01 \%$ and crude fiber digestibility of $53.78 \%$.
\end{abstract}

Keywords-Fermentation, Cocoa pod, Nitrogen source, Pleurotus osteratus

\section{INTRODUCTION}

The problem of poultry feed is still a concern today because poultry is still one of the most developed livestock commodities. The price of poultry feed which is unstable tends to be expensive and the level of availability which continues to decrease simultaneously results in the decline of poultry business. The high price of poultry feed is caused by the constituents used which are still imported and compete with human needs. The price of feed tends to change at any time depending on the situation, natural conditions, and the market.

One effort to reduce the problem of poultry feed is to replace conventional feed that is commonly used to prepare poultry rations with non-conventional feed ingredients. Generally, this non-conventional feed material comes from agricultural, livestock and industrial wastes. Non-conventional feed ingredients must be available continuously, in large volumes, easily available and inexpensive. One of the non-conventional feed ingredients that can be used as animal feed is cocoa pods obtained from cocoa fruit processing.

Indonesia ranks third as the world cocoa producer country after Pantai Gading and Ghana. West Sumatra is one of the cocoa-producing provinces with a production of 52.2 thousand tons with an area of plantation reaching 158.9 thousand hectares in 2017 (BPS, 2018). Cacao consists of $74 \%$ pods cacao, $2 \%$ placenta and $24 \%$ seeds (Harsini and Susilowati, 2010) so it can be estimated that pod cacao production of 38,628 thousand tons in 2017.

Pod cocoa contains crude protein $11.75 \%$, crude fat $11.75 \%$, NFE $34.95 \%$, crude fiber $32.12 \%$ (cellulose $22.11 \%$ and lignin 23.14\%) (Nuraini et al, 2013), and tannins $0.11 \%$ (Nuraini et al, 2012). If viewed in terms of nutrient content and continuous availability, the cocoa pod is quite the potential to be used as animal feed. Research that has been done shows that cocoa pod can be used as a source of animal feed (Tequia et al., 2004).

However, with the high content of crude fiber and the presence of theobromin antinutrient compounds in the cocoa pod is one of the limiting factors in giving to poultry, due to the limited ability of poultry to digest crude fiber and feeding continuously containing theobromine can reduce growth (Tarka et al. 1998).

One effort to reduce the content of crude fiber and minimize the content of antinutrient compounds in the cocoa pod is fermentation by utilizing the role of 
microorganisms. Microorganisms that are effective in degrading crude fiber, especially lignin, are Pleurotus ostreatus from the Basidiomycetes group known as highclass mushrooms that produce extracellular ligninolytic enzymes such as laccase, lignin peroxidase and manganese peroxidase (Periasamy and Natarajan 2004; Mayer and Staples 2002). Pleurotus Ostreatus also produces cellulase enzymes (Sudiana and Rahmansyah, 2002) which can work synergistically to break down cellulose into glucose through a catalyst process (Santos et al., 2012).

Fermentation in principle is influenced by several factors including the composition of the substrate, the dose of the inoculum and fermentation time. Fermentation using Pleurotus ostreatus requires a substrate containing carbon, nitrogen and mineral sources to support the growth and development of mycelium maximally pod cocoa itself can be used as a carbon source (C) in the substrate fermentation, but must be supplemented with a nitrogen source $(\mathrm{N})$ to get the balance $\mathrm{C}$ : $\mathrm{N}$ which is suitable for the growth and development of Pleurotus ostreatus mycelium. Sources of nitrogen $(\mathrm{N})$ that can be used are tofu waste, soy milk waste, and rice bran.

Tofu waste is a waste of soybean processing indus try that has nutrients namely crude protein at $28.36 \%$, crude fat $5.52 \%$, crude fiber $7.06 \%$ and NFE $45.44 \%$ (Nuraini et al., 2012). High crude protein content in tofu waste can be used as a source of $\mathrm{N}$ for the growth of mycelium. Muhfudz (2006) states that tofu waste contains lys ine and methionine amino acids and calcium which is quite high.

Soy milk waste is a waste of the soybean processing industry such as tofu waste but different in processing. Soy milk waste has a high crude protein content of $27.62 \%$, this content can be used as a source of $\mathrm{N}$ for mycelium growth. Other nutritional content of crude fat is $2.95 \%$, NFE $52.66 \%$, crude fiber $13.81 \%$ and ash $2.96 \%$, $\mathrm{Ca} 0.09 \%, \mathrm{P} 0.04 \%$ (Muis et al, 2009).

Rice bran is the biggest by-product of rice milling process which contains metabolic energy of $2980 \mathrm{kcal} /$ $\mathrm{kg}$, crude protein $12.9 \%$, crude fat $13 \%$, crude fiber $11.4 \%$, $\mathrm{Ca} 0.07 \%$, phosphorus $0.22 \%, \mathrm{Mg} 0.95 \%$ and $9 \%$ moisture content (Saputra, 2015). Rice bran is also rich in vitamin B complex and mineral components such as iron, aluminum, calcium, magnesium, manganese, phosphorus, and zinc (Astawan, 2010). It is hoped that cocoa pod fermented using Pleurotus ostreatus with different nitrogen sources can produce optimal cellulase and laccase enzymes to reduce fiber content and increase the digestibility of crude fiber.

\section{MATERIALS AND METHODS}

\subsection{Materials}

The ingredients used are cocoa pod, tofu waste, soy milk waste and rice bran. The fungus used is Pleurotus ostreatus. The equipment used is analytical scales, autoclaves, laminar airflow, ovens, a set of equipment for proximate analysis, cellulase enzyme activity and laccase enzyme activity.

\subsection{Method}

The design used is a Completely Randomized Design (CRD) Factorial $3 \times 3 \times 3$ with 2 replications. Factor $A$ is a substrate composition consisting of 3 (three) levels, namely:

A $1=80 \%$ cocoa pod $+20 \%$ tofu waste

$\mathrm{A} 2=80 \%$ cocoa pod $+20 \%$ soy milk waste

$\mathrm{A} 3=80 \%$ cocoa pod $+20 \%$ rice bran

Factor B is the dose of inoculum which consists of 3 (three) levels, namely:

$\mathrm{B} 1=6 \%$ dry matter of the amount of substrate

$\mathrm{B} 2=8 \%$ dry matter out of the amount of substrate

$\mathrm{B} 3=10 \%$ of dry matter from the amount of substrate

Factor $\mathrm{C}$ is the fermentation time consisting of 3 (three) levels, namely:

$\mathrm{C} 1=7$ days

$\mathrm{C} 2=9$ days

C3 = 11 days

\subsection{Research Implementation}

This research activity is fermenting cocoa pods with tofu waste, soy milk waste and rice bran. Cocoa pod is cleaned first then chopped $0.5-1 \mathrm{~cm}$. Tofu and soy milk wastes are squeezed to reduce water content. Weigh the substrate by composition ( $80 \%$ cocoa pod and $20 \%$ for tofu waste, soy milk waste and rice bran). Homogenize the three substrates then add $7 \mathrm{ml}$ of Mineral Brook, the substrate water content is $\pm 70 \%$. Sterilize all substrates in the autoclave at $121^{0}$ for 15 minutes. Pleurotus ostreatus inoculation according to treatment (6,8 and 10\%). Incubation according to treatment (7, 9 and 11 days). Fermentation products will be analyzed for crude fiber content (AOAC method, 1990), crude fiber digestibility (Sibbald method, 1975), cellulase enzyme activity (Nelson method, 1944) and laccase enzyme activity (Buswell et al., 1995).

\section{RESULT AND DISCUSSION}

\subsection{Cellulase enzyme activity}

Statistical analysis showed that there was no interaction between the composition of the substrate, inoculum dose and fermentation time but the interaction was significantly different $(\mathrm{P}<0.05)$ found in the composition of the substrate with the fermentation time 
on the activity of cellulase enzymes ( $\mathrm{U} / \mathrm{ml}$ ) cocoa pod fermented with Pleurotus ostreatus (Table 1).

DMRT (Duncan Multiple Range Test) showed that cellulase enzyme activity in A1C3 treatment (80\% cocoa pod and $20 \%$ tofu waste with 11 days fermentation time) had no significant effect $(\mathrm{P}>0.05)$ from $\mathrm{A} 1 \mathrm{C} 2$ treatment (80\% pod cacao and $20 \%$ tofu waste with 9 days fermentation time), A2C2 treatment (80\% cocoa pod and $20 \%$ soy milk waste with 9 days fermentation time) and A2C3 treatment $(80 \%$ cocoa pod and $20 \%$ soy milk waste with 11 days fermentation time); but significantly ( $\mathrm{P}$ $<0.05)$ higher than other treatments.

Table 1. The average cellulase enzyme activity $(\mathrm{U} / \mathrm{ml})$

\begin{tabular}{|c|c|c|c|c|c|}
\hline \multirow{2}{*}{$\begin{array}{c}\text { Substrate } \\
\text { (A) }\end{array}$} & \multirow{2}{*}{$\begin{array}{l}\text { Inoculum } \\
\text { dose }(B)\end{array}$} & \multicolumn{3}{|c|}{$\begin{array}{l}\text { Fermentation time } \\
\text { (C) }\end{array}$} & \multirow[t]{2}{*}{ Average } \\
\hline & & $\mathrm{C} 1$ & $\overline{\mathrm{C} 2}$ & $\mathrm{C} 3$ & \\
\hline \multirow{3}{*}{ A 1} & $\bar{B} 1$ & 2,02 & 2,52 & 2,69 & 2,41 \\
\hline & B2 & 2,18 & 2,77 & 2,87 & 2,61 \\
\hline & B3 & 2,37 & 2,80 & 3,03 & 2,73 \\
\hline Total & & 6,56 & 8,70 & 8,58 & \\
\hline Average & & $2,19^{b}$ & $2,70^{a}$ & $2,86^{a}$ & \\
\hline \multirow{3}{*}{ A2 } & $\overline{\mathrm{B} 1}$ & 1,99 & 2,40 & 2,52 & 2,30 \\
\hline & B2 & 2,13 & 2,62 & 2,68 & 2,48 \\
\hline & B3 & 2,22 & 2,76 & 2,85 & 2,61 \\
\hline Total & & 6,33 & 7,78 & 8,05 & \\
\hline Average & & $2,11^{b}$ & $2,59^{\mathrm{a}}$ & $2,68^{a}$ & \\
\hline \multirow{3}{*}{ A 3} & $\overline{\mathrm{B} 1}$ & 1,94 & 2,05 & 2,18 & 2,05 \\
\hline & B2 & 2,02 & 2,12 & 2,24 & 2,12 \\
\hline & B3 & 2,11 & 2,28 & 2,33 & 2,24 \\
\hline Total & & 6,07 & 6,44 & 6,74 & \\
\hline Average & & $2,02^{b}$ & $2,15^{b}$ & $2,25^{b}$ & \\
\hline
\end{tabular}

The high activity of cellulase enzymes in $\mathrm{A} 1 \mathrm{C} 2$,

$\mathrm{A} 1 \mathrm{C} 3, \mathrm{~A} 2 \mathrm{C} 2$, and $\mathrm{A} 2 \mathrm{C} 3$ treatments is due to the presence of substrate composition and fermentation time which are suitable for the growth of Pleurotus ostreatus. On $80 \%$ cocoa pod and $20 \%$ tofu waste substrate and $80 \%$ cocoa pod and $20 \%$ soymilk waste substrate, it appears that the growth of Pleurotus ostreatus is fertile, white and evenly almost covered the entire substrate. This is supported by Gunam et al., (2011) that there is a correlation between protein content and enzyme activity produced when viewed from substrate concentration and fermentation time. In environmental conditions with high protein content produced, the enzyme activity is also high and otherwise if, in conditions where the protein content produced is low, it appears that the activity of the resulting enzyme is low.

Fermentation time allows mycelium to flourish to fill the substrate so that more cellulase enzymes are produced. According to Setyawan (2007) that the fermentation time is closely related to the time that can be used by microbes to grow and multiply so that the enzyme activity increases. The longer time of fermentation causes the fungus to flourish and the cellulase enzymes produced from hyphae will be more numerous, besides the conditions in the substrate also support the cellulase enzyme to move, so that the cellulase enzyme is more active in breaking down cellulose into glucose.

The selected treatment based on its efficiency was found in A1C2 $(80 \%$ cocoa pod and $20 \%$ tofu waste with 9 days fermentation time) with cellulase enzyme activity 2,70 U/ml. This result is higher than Doharne (2015) where cacao pod fermented with P.chrysosporium and a dose of inoculum $7 \%$ with a fermentation period of 10 days and continued fermentation with N.crassa $9 \%$ with a fermentation period of 4 days has an enzyme activity of 0 , $10 \mathrm{U} / \mathrm{ml}$.

\subsection{Laccase enzyme activity}

Statistical analysis showed that there was no interaction between the composition of the substrate, inoculum dose and fermentation time but the interaction was significantly different $(\mathrm{P}<0.05)$ found in the composition of the substrate with the fermentation time on the activity of laccase enzymes ( $\mathrm{U} / \mathrm{ml}$ ) cocoa pod fermented with Pleurotus ostreatus (Table 2).

Table 2. The average laccase enzyme activity $(\mathrm{U} / \mathrm{ml})$

\begin{tabular}{|c|c|c|c|c|c|}
\hline \multirow{2}{*}{$\begin{array}{c}\text { Substrate } \\
\text { (A) }\end{array}$} & \multirow{2}{*}{$\begin{array}{l}\text { Inoculu } \\
\text { m dose } \\
\text { (B) }\end{array}$} & \multicolumn{3}{|c|}{ Fermentation time $(\mathrm{C})$} & \multirow{2}{*}{$\begin{array}{c}\text { Averag } \\
\text { e }\end{array}$} \\
\hline & & $\mathrm{C} 1$ & C2 & C3 & \\
\hline \multirow{3}{*}{ A1 } & $\overline{\mathrm{B} 1}$ & 9,78 & 11,75 & 12,09 & 11,21 \\
\hline & $\bar{B} 2$ & 10,59 & 12,27 & 12,56 & 11,81 \\
\hline & B3 & 11,11 & 12,96 & 13,02 & 12,36 \\
\hline Total & & 31,48 & 36,98 & 37,67 & \\
\hline \multirow{2}{*}{ Average } & & 10,49 & 12,33 & 12,56 & \\
\hline & & c & a & a & \\
\hline \multirow{3}{*}{ A 2} & $\bar{B} 1$ & 9,32 & 11,23 & 11,40 & 10,65 \\
\hline & $\overline{\mathrm{B} 2}$ & 10,47 & 11,98 & 12,09 & $\overline{11,52}$ \\
\hline & $\bar{B} 3$ & 10,53 & 12,44 & 12,91 & 11,96 \\
\hline Total & & 30,32 & 35,65 & $\overline{36,40}$ & \\
\hline \multirow{2}{*}{ Average } & & 10,11 & 11,88 & 12,13 & \\
\hline & & c & a & a & \\
\hline \multirow{3}{*}{ A3 } & $\overline{\mathrm{B} 1}$ & 8,45 & 9,66 & 10,65 & 9,59 \\
\hline & $\overline{\mathrm{B} 2}$ & 9,78 & 10,36 & 11,00 & 10,38 \\
\hline & $\overline{\mathrm{B} 3}$ & 10,13 & 11,05 & 11,98 & 11,05 \\
\hline Total & & 28,36 & 31,08 & 33,62 & \\
\hline \multirow{2}{*}{ Average } & & & 10,36 & 11,21 & \\
\hline & & $9,45^{d}$ & . & b & \\
\hline
\end{tabular}

DMRT (Duncan Multiple Range Test) showed that laccase enzyme activity in A1C3 treatment (80\% cocoa pod and $20 \%$ tofu waste with 11 days fermentation time) had no significant effect $(\mathrm{P}>0.05)$ from A1C2 treatment ( $80 \%$ cacao pod and $20 \%$ tofu waste with 9 days fermentation time), A2C 2 treatment ( $80 \%$ cocoa pod and $20 \%$ soy milk waste with 9 days fermentation time) and 
A2C3 treatment $(80 \%$ cocoa pod and $20 \%$ soy milk waste with 11 days fermentation time); but significantly(P $<0.05)$ higher than other treatments.

The high activity of the laccase enzyme in $\mathrm{A} 1 \mathrm{C} 2$, $\mathrm{A} 1 \mathrm{C} 3, \mathrm{~A} 2 \mathrm{C} 2$, and $\mathrm{A} 2 \mathrm{C} 3$ treatments due to the presence of a $\mathrm{C}: \mathrm{N}$ ratio balance in the four treatments, can be seen from the fertile growth of mycelium compared to other treatments. The fertility of the mycelium is also affected by the fermentation time, where the fermentation time gives the mycelium opportunity to continue to grow. The C: $\mathrm{N}$ ratio of $80 \%$ cocoa pod and $20 \%$ tofu waste is 12.16: 1 , and $80 \%$ cocoa pod and $20 \%$ soy milk waste is 12.47: 1 . This is supported by the opinion of Gianfreda $e t$ al. (1999) that laccase production is strongly influenced by the concentration of nitrogen in the culture medium and the carbon source used (Galhaup et al., 2003). Furthermore, Nadeem et al. (2014) that carbon and nitrogen sources at the right ratio are needed for propagation and enzyme production. Basidiomycetes fungi including Pleurotus ostreatus have different responses to carbon sources and their concentration in the medium for growth. Significant laccase secretion occurs when the concentration of carbon sources in the growth medium reaches a low level. The best $\mathrm{C}$ : $\mathrm{N}$ ratio for the growth of Pleurotus ostreatus is $10-15: 1$ and results in maximum laccase production, where an increase in $\mathrm{C}: \mathrm{N}$ ratio will further reduce laccase production significantly.

Majeau et al. (2010) reported that laccase enzyme production was influenced by factors of nutrient availability such as carbon and nitrogen, concentration and $\mathrm{C}$ : $\mathrm{N}$ ratio as well as other factors such as characteristic and concentration of the inducer. The optimum concentration of organic carbon in growth media has an important role in laccase production. In the white-rot fungus group, the production of the enzyme laccase main role in ligninolytic activity (Bonnen et al., 1994). Furthermore, Ardon et al. (1998) show a strong indication that the activity of the laccase enzyme can increase the level of lignin degradation. Among the Basidiomycetes groups of white rot species dominant studied are Pleurotus ostreatus and Tramets versicolor because of their ability to mineralize lignin through the secretion of oxidative enzymes such as laccase (Halburgi, 2011) known as an efficient enzyme in degrading lignin (Bernardi et al., 2008).

The selected treatment based on its efficiency was found in A1C2 (80\% cocoa pod and $20 \%$ tofu waste with 9 days fermentation time) with laccase enzyme activity of 12,33 U/ml. Pleurotus ostreatus also produces laccase enzymes in palm sludge fermentation obtained of 12.73 $\mathrm{U} / \mathrm{ml}$.

\subsection{Reduction of crude fiber}

Statistical analysis showed that there was no interaction between the composition of the substrate, inoculum dose and fermentation time but the interaction was significantly different $(\mathrm{P}<0.05)$ found in the composition of the substrate with the fermentation time on the reduction of crude fiber (\%DM) cocoa pod fermented with Pleurotus ostreatus (Table 3).

DMRT (Duncan Multiple Range Test) showed that reduction crude fiber in A1C3 treatment ( $80 \%$ cocoa pod and $20 \%$ tofu waste with 11 days fermentation time) had no significant effect $(\mathrm{P}>0.05)$ from $\mathrm{A} 1 \mathrm{C} 2$ treatment $(80 \%$ pod cacao and $20 \%$ tofu waste with 9 days fermentation time), A2C2 treatment ( $80 \%$ cocoa pod and $20 \%$ soy milk waste with 9 days fermentation time) and $\mathrm{A} 2 \mathrm{C} 3$ treatment ( $80 \%$ cocoa pod and $20 \%$ soy milk waste with 11 days fermentation time); but significantly $(\mathrm{P}<0.05)$ lower than other treatments.

Table 3. The average reduction of crude fiber (\%DM)

\begin{tabular}{|c|c|c|c|c|c|}
\hline \multirow{2}{*}{$\begin{array}{c}\text { Substrate } \\
\text { (A) }\end{array}$} & \multirow{2}{*}{$\begin{array}{c}\text { Inoculu } \\
\text { m dose } \\
\text { (B) }\end{array}$} & \multicolumn{3}{|c|}{ Fermentation time $(C)$} & \multirow{2}{*}{$\begin{array}{c}\text { Averag } \\
\text { e }\end{array}$} \\
\hline & & $\mathrm{C} 1$ & $\mathrm{C} 2$ & $\mathrm{C} 3$ & \\
\hline \multirow{3}{*}{ A1 } & $\overline{\mathrm{B} 1}$ & 33,02 & 39,95 & 46,57 & 39,85 \\
\hline & B2 & 32,09 & 43,95 & 46,78 & 40,94 \\
\hline & B3 & 35,31 & 48,14 & 49,40 & 44,28 \\
\hline Total & & 100,42 & 132,04 & 142,75 & \\
\hline \multirow{2}{*}{ Average } & & $33,4^{c}$ & $44,01^{a}$ & & \\
\hline & & d & b & $47,58^{a}$ & \\
\hline \multirow{3}{*}{ A 2} & B1 & 30,19 & 39,71 & 38,48 & 36,13 \\
\hline & B2 & 32,34 & 41,83 & 44,46 & 39,54 \\
\hline & B3 & 33,40 & 46,36 & 47,67 & 42,48 \\
\hline Total & & 95,93 & 127,90 & 130,61 & \\
\hline \multirow{2}{*}{ Average } & & $31,98^{c}$ & $42,6^{a}$ & $43,54^{\mathrm{a}}$ & \\
\hline & & d & b & b & \\
\hline \multirow{3}{*}{ A3 } & B1 & 20,06 & 22,61 & 35,56 & 26,08 \\
\hline & B2 & 21,55 & 29,88 & 38,63 & 30,02 \\
\hline & B3 & 30,44 & 33,82 & 40,13 & $\mathbf{3 4 , 8 0}$ \\
\hline Total & & 72,06 & 86,31 & 114,33 & \\
\hline \multirow{2}{*}{ Average } & & & $28,77^{d}$ & $38,11^{b}$ & \\
\hline & & $24,02^{\mathrm{e}}$ & e & c & 334,11 \\
\hline
\end{tabular}

The decrease in crude fiber in $\mathrm{A} 1 \mathrm{C} 3, \mathrm{~A} 1 \mathrm{C} 2, \mathrm{~A} 2 \mathrm{C} 3$, and A2C2 treatments was due to the activity of cellulase enzymes in the four treatments, which were respectively $2.86 \%, 2.70 \%, 2.68 \%$ and $2.59 \%$. High cellulase enzyme activity is related to substrate composition (C: $\mathrm{N}$ balance) and fermentation time suitable for Pleurotus ostreatus to grow and flourish. Pleurotus ostreatus produces cellulase enzymes (Sudiana and Rahmansyah, 2002) which can work synergistically to break down cellulose into glucose through a catalyst process (Santos et al., 2012). Substrate composition that has a balanced $\mathrm{C}$ : $\mathrm{N}$ ratio can accelerate the growth of Pleurotus ostreatus, because fungi need carbon and nitrogen for its growth. Nadeem et al., (2014) 
stated that the best $\mathrm{C}: \mathrm{N}$ ratio range for the growth of Pleurotus ostreatus is 10-15: 1 .

Fermentation time allows the mycelium to grow more optimally and produce enzymes to degrade crude fiber components. This is supported by Musnandar (2004) where the longer the fermentation, the greater the opportunity for enzyme complex to degrade crude fiber components into simple sugars. This increase in simple sugars will increase the growth of fungal colonies, especially high doses of inoculum so that the production of enzymes increases which in turn increases the degradation of crude fiber on the substrate. The more fertile the mycelium, the higher the activity of the cellulase enzyme produced in degrading the fiber components of the fiber on the substrate.

The longer fermentation will cause the process of fungal metabolism to increase so that more energy is released by the fungus by degrading various energy sources in the substrate such as crude fiber. Furthermore, Perez et al. (2001) explained that each microfungus has a different ability to decompose the substrate. The longer the incubation period, the more complex the compounds that are broken down by microorganisms into simpler compounds that can accumulate into energy.

The selected treatment based on its efficiency was found in the A1C2 treatment (80\% cocoa pod and $20 \%$ tofu waste with 9 days fermentation time) of $44,01 \%$. This result is higher than Doharne (2015) where cocoa pods fermented with P.chrysosporium with $7 \%$ inoculum dose with 10 days fermentation time and continued fermentation with $N$.crassa $9 \%$ with 4 days fermentation time decreased fiber content of $25,47 \%$.

\subsection{Crude fiber digestibility}

Statistical analysis showed that there was no interaction between the composition of the substrate, inoculum dose and fermentation time but the interaction was significantly different $(\mathrm{P}<0.05)$ found in the composition of the substrate with the fermentation time on the crude fiber digestibility (\%DM) cocoa pod fermented with Pleurotus ostreatus (Table 4).

Table 4. The average crude fiber digestibility (\%DM)

\begin{tabular}{|c|c|c|c|c|c|}
\hline \multirow{2}{*}{$\begin{array}{c}\text { Substrat } \\
\text { e (A) }\end{array}$} & \multirow{2}{*}{$\begin{array}{c}\text { Inoculu } \\
\text { m dose } \\
\text { (B) }\end{array}$} & \multicolumn{3}{|c|}{ Fermentation time $(\mathrm{C})$} & \multirow{2}{*}{$\begin{array}{c}\text { Averag } \\
\text { e }\end{array}$} \\
\hline & & $\mathrm{C} 1$ & $\mathrm{C} 2$ & $\mathrm{C} 3$ & \\
\hline \multirow{3}{*}{ A 1} & $\overline{\mathrm{B} 1}$ & 43,77 & 48,60 & 49,30 & 47,22 \\
\hline & B2 & 47,29 & 54,87 & 56,82 & 52,99 \\
\hline & B3 & 49,53 & 57,86 & 58,76 & 55,38 \\
\hline \multirow{2}{*}{ Total } & & 140,5 & & 164,8 & \\
\hline & & 8 & 161,33 & 9 & \\
\hline Average & & $46,86^{b}$ & $53,78^{a}$ & $54,96^{a}$ & \\
\hline \multirow{2}{*}{ A2 } & $\overline{\mathrm{B} 1}$ & 42,31 & 46,33 & 48,01 & $\mathbf{4 5 , 5 5}$ \\
\hline & B2 & 45,75 & 49,79 & 53,29 & 49,61 \\
\hline
\end{tabular}

\begin{tabular}{cccccc} 
& B3 & 49,30 & 51,31 & 55,28 & $\mathbf{5 1 , 9 6}$ \\
\hline \multirow{2}{*}{ Total } & & 137,3 & & 156,5 & \\
& & 6 & 147,43 & 8 & \\
\hline \multirow{2}{*}{ Average } & & $\mathbf{4 5 , 7 9}^{\mathbf{b}}$ & $\mathbf{4 9 , 1 4}^{\mathbf{a}}$ & & \\
& & $\mathbf{5 2 , 1 9}^{\mathbf{a}}$ & \\
\hline \multirow{2}{*}{ A3 } & B1 & 42,01 & 43,12 & 44,17 & $\mathbf{4 3 , 1 0}$ \\
& B2 & 43,39 & 44,09 & 46,54 & $\mathbf{4 4 , 6 7}$ \\
& B3 & 46,16 & 46,70 & 47,67 & $\mathbf{4 6 , 8 4}$ \\
\hline \multirow{2}{*}{ Total } & & 131,5 & & 138,3 & \\
& & 6 & 133,91 & 8 & \\
\hline Average & & $\mathbf{4 3 , 8 5}^{\text {b }}$ & $\mathbf{4 4 , 6 4}^{\text {b }}$ & $\mathbf{4 6 , 1 3}^{\text {b }}$ & \\
\hline
\end{tabular}

DMRT (Duncan Multiple Range Test) showed that laccase enzyme activity in A1C3 treatment (80\% cocoa pod and $20 \%$ tofu waste with 11 days fermentation time) had no significant effect $(\mathrm{P}>0.05)$ from A1C2 treatment ( $80 \%$ cacao pod and $20 \%$ tofu waste with 9 days fermentation time), A2C 2 treatment ( $80 \%$ cocoa pod and $20 \%$ soy milk waste with 9 days fermentation time) and A2C3 treatment ( $80 \%$ cocoa pod and $20 \%$ soy milk waste with 11 days fermentation time); but significantly (P $<0.05)$ higher than other treatments.

The high digestibility of crude fiber in the $\mathrm{A} 1 \mathrm{C} 3$, $\mathrm{A} 1 \mathrm{C} 2, \mathrm{~A} 2 \mathrm{C} 3$ and $\mathrm{A} 2 \mathrm{C} 2$ treatments is due to the low crude fiber content in the four treatments due to the high activity of cellulase and lacase enzymes due to the $\mathrm{C}: \mathrm{N}$ ratio in a balanced substrate composition and long fermentation time so high coarse fiber digestibility. Prawitasari et al. (2012) states that the lower crude fiber content in the ration causes the higher digestibility of crude fiber and otherwise. The content of crude fiber in the ration greatly affects the digestibility of crude fiber.

Maynard et al., (2005) stated that the digestibility of crude fiber is influenced by several factors including fiber content in feed, composition of crude fiber and microorganism activity. Poultry is difficult to digest high crude fiber because fiber-digesting microbes are only in the cecum and are few in number. Wahju (2004) states that crude fiber has bulky properties which consists of cellulose, hemicellulose and lignin which are mostly difficult to digest by poultry.

Van Soest (1985) states that the digestibility and digestion rate of hemicellulose is higher than that of cellulose, this is due to the constituent components and the abrasive components of cellulose, lignin, and silica cannot be digested by poultry, but the hemicellulose component can still be hydrolyzed by the acid content in proventiculus and gizzard.

Scott et al., (1982) reported that broiler can utilize energy from hemicellulose through the hydrolysis process that is in the proventiculus and gizzard or possibly digestion by microbes in the intestine to produce energy. 
The selected treatment based on its efficiency was found in the A1C2 treatment (80\% cocoa pod and 20\% tofu waste with 9 days fermentation time) of $53.78 \%$.

\section{CONCLUSION}

It can be concluded that the selected treatment was found in the composition of $80 \%$ cocoa pod and $20 \%$ tofu waste with 9 days fermentation time (A1C2). In this condition cellulase enzyme activity was obtained of 2.70 $\mathrm{U} / \mathrm{ml}$, lactase enzyme activity of $12.33 \mathrm{U} / \mathrm{ml}$, crude fiber decreased of $44,01 \%$ and crude fiber digestibility of $53.78 \%$.

\section{REFERENCES}

[1] AOAC.1990. Official Method of Analy sis. Association of Official Analytical Chemists. Maryland.

[2] Ardon, O. Z, Karem and Y. Hadar,. 1998. Enhancement of lignin degradation and laccase activity in Pleurotus ostreatus by cotton stalk extract. Can. J. Microbiol. 44: 676-680

[3] Astawan M. 2010. Potensi Dedak dan Bekatul Beras Sebagai Ingredient Pangan dan Produk Pangan Fungsional. Gramedia Pustaka Utama, Jakarta.

[4] Bernardi, E., E. Minotto and J.S. Nascimento (2008). Aproveitamento de residuo de curtume como suplemento no cultivo de Pleurotus ostreatus. Arq. Inst. Biol., 72: 243-246.

[5] Bonnen AM, Anton LH, Orth AB. 1994. Lignindegrading enzymes of the commercial button mushroom, Agaricus bisporus. Appl. Environ. Microbiol 60:960-965.

[6] Buswell JK, Cai YJ \& Chang ST (1995). Effect of nutrient nitrogen on manganese peroxidase and laccase production by Lentinula (Lentinus) edodes. FEMS Microbiol Lett 128, 81-88.

[7] Doharne, Pane. 2015. Peningkatan kualitas kulit buah coklat melalui fermentasi dengan Phanerochate chrysosporium dan Neurospora crassa dan aplikasinya dalam ransum broiler. Thesis. Fakuktas Peternakan Universitas Andalas. Padang.

[8] Galhaup, C., H. Wagner, B. Hinterstoisser \& D. Haltrich. 2003. Increased production of laccase by the wood degrading basidiomycete Trametes pubescens. Enzyme Microb. Technol., 30, 529-536.

[9] Gianfreda, I., F. Xu \& J. M Bollag .1999. Laccase a useful group of oxidoreductive enzymes. Biorem. J., 3, 1-25.

[10] Gunam, I.B.W., Aryanta, W. R., dan I.B.S.N, Darma. 2011. Produksi selulase kasar dari kapang Trichoderma viride dengan perlakuan konsentrasi substrat ampas tebu dan lama fermentasi. Jurnal Biologi XV (2) : 29 - 33.

[11] Halburgi, V.M., S. Sharma, M. Sinha, T.P. Singh and T.B. Karegoudar (2011). Purification and characterization of a thermostable laccase from the ascomycetes Cladosporium cladosporioides and its applications. Proc. Biochem., 46: 1146-1152.
[12] Harsini, T., Susilowati, 2010.Pemanfaatan kulit buah kakao dari limbah perkebunan kakao sebagai bahan baku pulp dengan proses organosolv. Jurnal Ilmiah Teknik Lingkungan Vol. 2 No. 2:80-89.

[13] Majeau J A, Brar S K \& Tyagi R D .2010. Laccases for removal of recalcitrant and emerging pollutants. Bioresource technology, 101(7), 2331-2350.

[14] Mayer AM and R.C. Staples. 2002. Laccase: new functions for an old enzyme. Phytochemistry 60:131- 565.

[15] Maynard, L.A. Loosil, J.K. Hintz, H.F and Warner, R.G. , 2005. Animal Nutrition. (7th Edition) McGraw-Hill Book Company. New York, USA.

[16] Muhfudz, L. D. 2006. Ampas Tahu Fermentasi sebagai Bahan Pakan Ayam Pedaging. Caraka Tani, Jurnal IlmuIlmu Pertanian Vol 21 (1): 39-45.

[17] Muis,H.,L.Martaguri dan Mirnawati.2009. Teknologi bioproses ampas kedelai (soybean waste) untuk meningkatkan daya gunanya sebagai pakan unggas. Laporan Penelitian Fundamental Dirjen Pendidikan Tinggi Fakultas Peternakan, Universitas Andalas Padang.

[18] Musnandar, E. 2004. Pertumbuhan jamur Marasmius sp. pada substrat kelapa sawit untuk bahan pakan ternak. Majalah Ilmiah Angsana Vol. 08. No.3, Desember ; 25 30.

[19] Nadeem A, Baig S \& Sheikh N .2014. Mycotechnological production of laccase by Pleurotus ostreatus P1 and its inhibition study. J Anim Plant Sci 24(2), 492-502.

[20] Nelson, N., 1944. A photometric adaptation of the Somogyi method for the determination of glucose. Journal Biol. Chem, 153(2), 375-379.

[21] Nuraini, M.E. Mahata, dan Nirwansyah. 2012. Potensi ligninolitik dan selulolitik Phanerochaete chrysosporium dan karatenoid monakolin dari Monascus purpureus dalam meningkatkan kualitas kulit buah kakao sebagai pakan ternak. Laporan Strategis Nasional. Universitas Andalas.

[22] Nuraini., M. E. Mahata and Nirwansyah. 2013. Response of broiler fed cacao pod fermented by Phanerochate chrysosporium dan Monascus purpureus in the diet. Pakistan Journal of Nutrition 12(9):889-896

[23] Perez, L. M., Besoain, X., Reyes, M., Lempinasse, M., and Montealegre, J. 2001. The expression of enzymes involved in biological control of tomato phytopathogens by Trichodermad epends on the phytopathogen to be controlled and on the biocontrol isolate. IOBCWPRS Bulletin 24: 353 - 356 .

[24] Periasamy, K. and K. Natarajan. 2004. Role of lignocellulosic enzymes during basidiomata production by Pleurotus djamor var roseas. Indian Journal of Biotechnolog $3: 577-583$.

[25] Prawitasari, R. H., V. D. Y. B. Ismdi dan I. Estiningdriati. 2012. Kecernaan protein kasar dan serat kasar serta laju digesta pada ayam arab yang diberi ransum dengan berbagai level Azolla microphylla. Animal Agricultur Journal. 1 (1) : 471- 478.

[26] Santos, T.C., Gomes, D.P.P., Bonomo, R.C.F., Franco, M. 2012. Optimisation of Solid State Fermentation of Potato 
Peel for The Production of Cellulolytic Enzime. Food Chemistry. 133: 1299-1304.

[27] Saputra. 2015. Pemanfaatan Dedak Padi Sebagai Pakan Ternak. Diakses pada tanggal 02 Februari 2019.

[28] Scott, M.L, Nesheim M.C., and Young R. J., 1982. Nutrition of the Chickens. Second Ed. M.L. Scott and Associates Ithaca, New York.

[29] Setyawan, H. 2007. Peningkatan kualitas nutrisi duckweed melalui fermentasi menggunakan Trichoderma harzianium. Jurnal ilmu ternak Vol. 7 no.2:113-116.

[30] Sibbald, I. R. 1975. The effect of level intaken on metabolzable energy value measured with adult rooster. Poultry Sciences, (54) : 1990-1998.

[31] Sudiana IM dan Rahmansyah M, 2002. Aktivitas amilase dan selulase jamur tiram putih yang ditumbuhkan pada media ampas aren dan serbuk gergaji kayu. Jurnal Mikrobiologi Indonesia 7: 7-10.

[32] Tarka, S.M.Jr., Arnaud.M.J., Dvorchik.B.H and Vesell.ES, 1998. Theobromine kinetics and metabolic disposition clinical pharmacology and therapy 34: 546555.

[33] Tequia A., H. N. L. Endeley, \& A. C. Beynen. 2004. Broiler performance upon dietarysubstitution of cocoa husks for maize. Int. J. Poult. Sci. 3: 779782.Cognition.(2008). In Oxford reference online premium dictionary. Retrieved from http://www.oxfordreference.com

[34] Van Soest. P. J., 1982. Nutritional Ecology of the Ruminant. Commstock PublishingAssociates. Adevision of Cornell University Press. Ithaca and London

[35] Wahju, J. 2004. Ilmu Nutrisi Unggas. Cetakan ke-5. Gadjah Mada University Press, Yogy akarta. 